\title{
ANALISIS FAKTOR-FAKTOR YANG MEMPENGARUHI PENGANGGURAN PEREMPUAN
}

\author{
Ida Ayu Nyoman Saskara \\ Fakultas Ekonomi Universitas Udayana \\ David Kaluge \\ Fakultas Ekonomi Universitas Brawijaya
}

\begin{abstract}
The aim of this is to analyses women unemployment based on Indonesia Province using inflation, investment, women involvement at labor market, and also men involvement at labor market as independent varaibles. The panel data is used from 26 provinces in Indonesia for 5 years (2002-2006), using double log regression. The result shows that employing women have negative effect and significant, while employing men has positive effect and significant to the women employment. Inflation and investment have positive and negative effect but insignificant.
\end{abstract}

Keywords: inflation, investment, women unemployment and labor market

\section{A. LATAR BELAKANG}

Manusia diciptakan menjadi perempuan dan laki-laki yang saling melengkapi guna membangun suatu sinergi untuk kesejahteraan umat manusia. Namun dalam perkembangannya, telah terjadi dominasi oleh satu pihak terhadap pihak yang lainnya, sehingga menimbulkan diskriminasi, marjinalisasi, subordinasi, beban ganda, ataupun tindak kekerasan. Secara statistik, kaum perempuan menempati posisi yang kurang menguntungkan dalam berbagai aspek kehidupan dibandingkan dengan laki-laki. Situasi ini terjadi sebagai hasil dari akumulasi nilai sosio kultural suatu masyarakat.

Krisis yang terjadi secara mendadak dan diluar perkiraan pada akhir dekade 1990-an merupakan pukulan yang sangat berat bagi pembangunan Indonesia. Bagi kebanyakan orang, dampak dari krisis yang terparah dan langsung dirasakan, diakibatkan antara lain oleh inflasi. Antara tahun 1997 dan 1998 inflasi meningkat dari 6\% menjadi 78\%, sementara upah riil turun menjadi hanya sekitar sepertiga dari nilai sebelumnya. Akibatnya, kemiskinan meningkat tajam. Antara tahun 1996 dan 1999 proporsi orang yang hidup di bawah garis kemiskinan bertambah dari 18\% menjadi $24 \%$ dari jumlah penduduk. Pada saat yang sama, kondisi kemiskinan menjadi semakin parah, karena pendapatan kaum miskin secara keseluruhan menurun jauh di bawah garis kemiskinan.

Dampak krisis terhadap perempuan dan anak-anak tampaknya jauh lebih buruk. Bagi kebanyakan keluarga di mana sebelum krisis laki-laki dan perempuan sama-sama bekerja, kini perempuan terpaksa memperpanjang jam kerjanya karena kaum laki-laki telah kehilangan pekerjaan. Meningkatnya tingkat pengangguran terbuka yang mencapai 9,6 persen tahun 2003 meningkat menjdi 11,2 persen tahun 2005, walaupun tahun 2006 turun menjadi 10,9 persen. Bila dilihat pengangguran terbuka bagi perempuan tahun 2003 mencapai 12,7 persen, meningkat menjadi 14,7 persen pada tahun 2005 dan tahun 2006 turun menjadi 13,3 persen. Perkembangan tersebut menunjukkan bahwa secara rata-rata tingkat pengangguran terbuka baik secara total, maupun per 


\section{Journal of Indonesian Applied Economics Vol. 3 No. 2 Oktober 2009, 111-120}

jenis kelamin adalah meningkat, dan pengangguran terbuka perempuan dari tahun ke tahun adalah selalu lebih tinggi dibandingkan laki-laki. Hal tersebut berpotensi menimbulkan berbagai permasalahan sosial. Ekspresi diri diwujudnyatakan dalam bekerja. Karena itu Pemerintah menempatkan penciptaan kesempatan kerja sebagai salah satu sasaran pokok dalam Agenda Meningkatkan Kesejahteraan Rakyat yang dijabarkan ke dalam berbagai prioritas pembangunan yang memerlukan investasi baik yang bersumber dari dalam maupun luar negeri. Bagaimana kaum perempuan berperan dalam pembangunan dan iklim yang dibangun Pemerintah, sehingga secara keseluruhan dapat menurunkan tingkat pengangguran terbuka dengan menciptakan lapangan pekerjaan produktif.

Dari segi penawaran, pencari kerja perempuan lebih sedikit dari pada pencari kerja laki-laki. Demikian juga dari segi permintaan, lowongan kerja perempuan lebih sedikit dari pada lowongan kerja laki-laki. Secara persentase banyaknya lowongan kerja terdaftar terdapat pencari kerja terdaftar antara laki-laki dan perempuan masing-masing pada tahun 2005 secara berturut-turut 21,04 persen dan 22,78 persen. Dengan demikian peluang mendapatkan pekerjaan bagi perempuan lebih besar dibandingkan laki-laki.

Meningkatnya jumlah pengangguran terbuka selama 5 tahun terakhir, khususnya bagi perempuan adalah merupakan penomena yang tidak bisa dipungkiri, bagaimana tidak, beberapa upaya meningkatkan kedudukan dan peranan perempuan yang dilaksanakan selama ini telah menunjukan kemajuan dan keberhasilan, walaupun demikian, masih banyak ditemui berbagai permasalahan dan hambatan yang belum sepenuhnya dapat diselesaikan. Persamaan kedudukan, hak dan kewajiban, peranan serta kesempatan antara laki-laki dan perempuan belum dapat diwujudkan dengan baik. Keterlibatan perempuan dalam kegiatan ekonomi merupakan fenomena penting dalam era modernisasi dan globalisasi. Pada satu sisi masuknya perempuan ke dalam pasar kerja menggambarkan terjadinya pergeseran pembahagian kerja secara seksual. Saat ini batas sektor public dan domestik sebagai batas antara wilayah laki-laki dan perempuan menjadi kabur. Kondisi ini tidak hanya terjadi dilapisan sosial tertentu, tapi pada semua lapisan masyarakat. Dalam tulisan ini akan dibahas pengangguran perempuan serta faktor-faktor yang mempengaruhi seperti inflasi, investasi, keterlibatan perempuan di pasar kerja, dan juga keterlibatan laki-laki di pasar kerja.

\section{B. KAJIAN TEORITIS}

\section{Pertukaran Inflasi-Pengangguran (Unemployment-Inflation Tradeoff)}

Menurut Nothaft (2006), apabila tingkat pengangguran rendah, masalah inflasi akan dihadapi; makin rendah tingkat pengangguran, makin tinggi tingkat inflasi. Sebaliknya apabila terdapat masalah pengangguran yang serius, tingkat harga-harga adalah relatif stabil. Berarti tidak mudah untuk menciptakan penggunaan tenaga kerja penuh dan kestabilan harga secara serentak. Kurva yang mengambarkan hubungan diantara tingkat inflasi dan tingkat pengangguran dinamakan Kurva Philips. Sifat umum dari Kurva Philips adalah pada mulanya penurunannya adalah sangat curam, tetapi semakin lama semakin bertambah landai. Kurva phillip juga digunakan untuk menggambarkan hubungan diantara tingkat kenaikan harga dengan tingkat pengangguran. Namun dalam jangka panjang ada satu periode yang memungkinkan ekspektasi mengenai inflasi menyesuaikan sepenuhnya dengan inflasi yang sedang berlaku.

\section{Investasi, Inflasi dan Pengangguran}

Menurut Smith dan Zoega (2005), menytakan bahwa investasi menentukan efektivitas permintaan, pengangguran dan pasar kerja. Hubungan antara investasi dan pengangguran ditunjukkan dengan bahwa semakin tinggi investasi di harapkan dapat menciptakan lapangan pekerjaan sehingga dapat menekan pengangguran. Pendapat Wicksell (Vieneris, 1977:321) bahwa tingginya minat masyarakat untuk investasi selain expektasi return adalah juga untuk menciptakan 


\section{Analisis Faktor-Faktor yang Mempengaruhi Perempuan \\ Ayu dan Kaluge}

lapangan kerja, mengurangi pengangguran dalam rangka mewujudkan tujuan pembangunan yaitu masyarakat adil dan makmur. Seperti misal pemerintah ingin mengusahakan tingkat pengangguran lebih rendah, pengeluaran agregat bertambah dan mendorong perusahaan untuk menambah investasi agar produksi bisa bertambah sehingga memperoleh keuntungan yang lebih besar. Lebih banyak pekerja digunakan dan pengangguran turun, tetapi di satu sisi inflasi meningkat. Kenaikan inflasi mendorong para pekerja menuntut kenaikan upah, keuntungan perusahaan merosot dan bisa mengalami kerugian, Maka akibat yang ditimbulkan, para pengusaha mengurangi jumlah pekerja dan pengangguran meningkat.

\section{METODE PENELITIAN}

1. Data yang digunakan

Data yang digunakan dalam tulisan ini adalah data panel periode 2002-2006, untuk 26 propinsi di Indonesia. Data dikumpulkan dari Badan Pusat Statistik, seperti: pengangguran perempuan, perempuan bekerja, pengangguran laki-laki, laki-laki bekerja, inflasi dan investasi di Indonesia

2. Model yang Digunakan

Model yang digunakan untuk menganalisis faktor-faktor yang mempengaruhi pengangguran perempuan berdasarkan propinsi di Indonesia:

$$
\mathrm{Y}=\mathrm{F}(\mathrm{X} 1, \mathrm{X} 2, \mathrm{X} 3, \mathrm{X} 4)
$$

Model regresinya dalam bentuk double log tidak penuh adalah sbb: dimana:

$$
\log Y_{i t}=\beta_{0 i}+\beta_{1} \log X_{1 i t}+\beta_{2} \log X_{2 i t}+\beta_{3} X_{3 i t}+\beta_{4} \log X_{4 i t}+e_{i t .}
$$

$\log \mathrm{Y}_{\text {it }}$ adalah penganguran perempuan propinsi ke $\mathrm{i}$ tahun ke $\mathrm{t}$

$\log \mathrm{X}_{\text {lit }}$ adalah laki-laki bekerja propinsi ke $\mathrm{i}$ tahun ke $\mathrm{t}$

$\log \mathrm{X}_{2 \mathrm{it}}$ adalah perempuan bekerja propinsi ke $\mathrm{i}$ tahun ke $\mathrm{t}$

$\mathrm{X}_{3 \mathrm{it}}$ adalah laju inflasi propinsi ke $\mathrm{i}$ tahun ke $\mathrm{t}$

$\log \mathrm{X}_{4 \mathrm{it}}$ adalah investasi propinsi ke i tahun ke $\mathrm{t}$

Regresi dengan menggunakan data panel, yaitu kombinasi antara data cross section (26 Propinsi di Indonesia) dengan data time series (2002-2006). Menurut Hsiao (1995), penggunaan data panel dalam penelitian ekonomi mempunyai beberapa keunggulan dibandingkan dengan data runtun waktu atau data unit biasa. Pertama, dapat memberikan peneliti sejumlah data yang lebih besar, sehingga menaikkan derajat kebebasan (degrees of freedom) dan mengurangi kolinieritas diantara variabel penjelas, oleh karena itu akan menghasilkan estimasi ekonometrik yang efisien. Kedua, data panel dapat mengatasi masalah yang timbul ketika ada masalah penghilangan variabel (ommited-variabel). Secara umum bentuk model regresi data panel adalah sebagai berikut.

$$
Y_{i t}=\alpha_{i}+\sum_{k=2}^{K} \beta_{k i} X_{k i t}+\varepsilon_{i t}
$$

Di mana $i=1,2, \ldots \mathrm{N}$ merupakan unit cross section, dan $t=1,2, \ldots \mathrm{T}$ merupakan waktu pada time series. $Y_{i t}$ merupakan dependent variable dari individu $i$ pada waktu $t$, dan $X_{i t}$ adalah nilai dari $k$ non-stochastic explanatory variable untuk individu $i$ pada waktu $t$.

Ada dua pendekatan mendasar yang digunakan dalam menganalisis panel data, yaitu:

1. pendekatan fixed effect yang menetapkan bahwa $\alpha_{\mathrm{i}}$ adalah sebagai kelompok yang spesifik atau berbeda dalam constant term dalam model regresinya;

2. pendekatan random effect, meletakkan $\alpha_{\mathrm{i}}$ adalah gangguan spesifik kelompok, sama dengan $e_{\mathrm{it}}$, kecuali untuk masing-masing kelompok, tetapi gambaran tunggal yang memasukkan regresi sama untuk tiap-tiap periode. 


\section{Journal of Indonesian Applied Economics}

Vol. 3 No. 2 Oktober 2009, 111-120

\section{Uji signifikansi fixed effect}

Rasio $t$ untuk $a_{i}$ mengimplikasikan uji hipotesis bahwa $\alpha_{i}$ sama dengan nol, hipotesis ini bagaimanapun tidak digunakan untuk menguji dalam konteks regresi. Jika kita tertarik pada perbedaan antar group, kita dapat menguji hipotesis bahwa constant term adalah sama, dengan uji F. Dengan hipotesis nol, bahwa estimasi pooled least square adalah efisien. Rasio F yang digunakan untuk menguji adalah:

$$
F=\frac{\left(R S S_{u}-R S S_{p}\right) /(m)}{\left(R S S_{p}\right) /(n-k)}
$$

Dimana RSS adalah residual sum of squaree, $\mu$ mengindikasikan unrestricted model dan $p$ mengindikasikan pooled atau restricted model dengan satu constant term. F hitung akan dibandingkan dengan $\mathrm{F}$ kritis. Jika $\mathrm{F}$ hitung lebih besar dibanding $\mathrm{F}$ kritis maka metode fixed effect lebih baik digunakan dari pada metode OLS

\section{Uji signifikasi Random Effect}

Breusch dan Pagan (1980) dalam Greene (Greene, 2000) menyarankan lagrange multiplier test $(\mathrm{LM})$ untuk menguji random effect yang didasarkan pada residual $O L S$, untuk

$$
\begin{aligned}
& H_{0}: \sigma_{u}^{2}=0 \\
& H_{1}: \sigma_{u}^{2} \neq 0
\end{aligned}
$$

Uji statistiknya adalah

$$
\begin{aligned}
L M & =\frac{n T}{2(T-1)}\left[\frac{\sum_{i=1}^{n}\left[\sum_{t=1}^{T} e_{i t}\right]^{2}}{\sum_{i=1}^{n} \sum_{t=1}^{T} e_{i t}^{2}}-1\right]^{2} \\
& =\frac{n T}{2(T-1)}\left[\frac{\sum_{i=1}^{n}\left(T \bar{e}_{i}\right)^{2}}{\sum_{i=1}^{n} \sum_{t=1}^{T} e_{i t}^{2}}-1\right]^{2}
\end{aligned}
$$

Uji LM ini didasarkan pada distribusi chi-squares dengan degree of fredom sebesar jumlah variabel independent. Jika nilai LM statistik lebih besar dari nilai kritis statistik chi-square maka metode random effect lebih baik digunakan dari pada OLS.

\section{Uji Stasioner dan Kointegrasi}

Sebelum dilakukan analisis data akan dilakukan uji stasioner dan uji kointegrasi terhadap data, dimana uji stasioner dimaksudkan agar hasil regresi tidak lancung(spurious regression), yaitu hasil koefisien regresi signifikan secara statistik, nilai koefisien determinasi tinggi dan variabel dalam model saling berhubungan. Sedangkan uji konintegrasi dengan tujuan untuk melihat apakah ada hubungan jangka panjang antara variabel pengangguran perempuan dengan variabe-variabel yang mempengaruhi. 


\section{Analisis Faktor-Faktor yang Mempengaruhi Perempuan \\ Ayu dan Kaluge}

Dari hasil analisis uji stasioner dengan pendekatan model ADF (Augmented Dickeyfuller) diperoleh bahwa variabel $\mathrm{Y}, \mathrm{X} 2$ dan X3 adalah stasioner, sedangkan dengan model uji Philips-Perron (PP) semua variabel adalah stasioner pada alpha 5\%. Pada pembahan ini akan digunakan pendekatan Philips-Perron atas dasar pertimbangan adanya autokorelasi di dalam variabel gangguan.

Sementara hasil uji kointegrasi, ternyata 3 (tiga) dari 11(sebelas) hasil uji statistik adalah tidak signifikan pada alpha 5\%, yang berarti tidak terjadi kointegrasi yaitu tidak ada hubungan jangka panjang antara variabel pengangguran perempuan $(\mathrm{Y})$ dengan variabel-variabel yang mempengaruhi.

\section{Hasil Estimasi}

\section{Uji signifikansi Fixed Effect}

Untuk menguji apakah model digunakan metode Common Intercept atau Fixed Effect digunakan F hitung sebagai berikut:

Nilai statistik F kritis dengan nemurator 25 dan denumerator 103 pada $\alpha=5 \%$ adalah 1,61 . Dengan demikian F hitung $(21,05)$, sumber: lamp 4, lebih besar dari F statistik maka yang digunakan adalah metode Fixed Effect.

\section{Uji signifikansi Random Effect}

Untuk menguji apakah model digunakan metode Common Intercept atau Random Effect digunakan rumus berikut:

Sedangkan nilai kritis tabel chi-squares dengan df sebesar 4 pada $\alpha=5 \%$ sebesar 9,44. Dengan demikian secara statistik signifikan. Model Random Effect lebih tepat dibandingkan metode OLS. Sumber perhitungan.

\section{Uji Signifikansi Fixed Effect atau Random Effect}

Setelah dibahas teknik yang lebih tepat adalah Fixed Effext dan Random Effect dibanding OLS, maka perlu diuji lagi model mana yang dipilih. Uji Hausman mendasarkan pada ide bahwa metode Fixed Effect dan GLS adalah efisien sedangkan metode OLS tidak efisien, dilain pihak alternatifnya metode OLS efisien sedangkan GLS tidak. Uji hipotesis nulnya adalah hasil estimasi keduanya tidak berbeda. Unsur yang dilihat dalam uji ini adalah kovarian matrik dari perbedaan vektor $\left\lfloor\hat{\beta}-\hat{\beta}_{G L S}\right\rfloor$ :

Hasil metode Hausman (h) adalah bahwa perbedaan covarian dari estimator yang efisien dengan estimator yang tidak efisien adalah nol. Uji ini mengikuti kriteia Wald dengan distribusi chisquare sbb:

$$
m=\hat{q}^{\prime} \operatorname{Var}(\hat{q})^{-1} \hat{q}
$$




\section{Journal of Indonesian Applied Economics Vol. 3 No. 2 Oktober 2009, 111-120}

Dimana:

dengan df sebanyak $\mathrm{k}$, dimana $\mathrm{k}$ adalah jumlah variabel independen. Jika nilai statistik $\mathrm{h}$ lebih besar dari nilai kritis maka model yang tepat adalah model Fixed Effect, dan sebaliknya jika nilai statistik h lebih kecil dari nilai kritis maka model yang tepat adalah Random Effect. Uji Hausman dengan program Eviews(langkahnya ada di lampiran 5, diperoleh hasil:

$$
m=\hat{q}^{\prime} \operatorname{Var}(\hat{q})^{-1} \hat{q}=3,9231
$$

Sedangkan nilai kritis chi-square dengan df 4 pada $\alpha=5 \%$ sebesar 9,43 maka model yang tepat untuk menganalisis pengangguran perempuan antar propinsi adalah model Random Effect.

Hasil perhitungan dengan metode Random Effect adalah sebagai berikut:

$$
\begin{aligned}
& \log \hat{Y}=-0,9437+1,7967 \log \mathrm{X}_{1}-0,5259 \log \mathrm{X}_{2}+0,00045 \mathrm{X}_{3}-0,00016 \log \mathrm{X}_{4} \\
& \mathrm{t}=(-4,7769) \quad(8,6632)^{*} \quad(-2,8226)^{*} \quad(1,7224) \quad(0,0434) \\
& \mathrm{R}^{2}=0,9014 ; \quad \mathrm{dw}=0,7270
\end{aligned}
$$

\section{HASIL DAN PEMBAHASAN}

Dari hasil perhitungan di atas dapat dijelaskan sebagai berikut: 1,7967 adalah koefisien dari variabel laki-laki bekerja $\left(\mathrm{X}_{1}\right)$ yang artinya jika laki-laki bekerja naik $1 \%$ ceteris paribus, maka pengangguran perempuan naik $1,7967 \%$, dan signifikan pada $\alpha=1 \%$. Secara logika teori bila laki-laki bekerja meningkat, pengangguran perempuan bisa menurun, bila proporsi pencari kerja relatif sama. Pada kasus ini terjadi walaupun laki-laki bekerja meningkat tetapi pengangguran perempuan juga meningkat. Hal ini bisa disebabkan oleh proporsi peningkatan pencari kerja (khususnya perempuan) lebih tinggi dibandingkan proporsi peningkatan perempuan bekerja, atau bisa juga karena peluang kerja bagi laki-laki memang lebih tinggi dibandingkan perempuan. Sedangkan koefisien variabel perempuan bekerja $\left(\mathrm{X}_{2}\right)$, sebesar $-0,5259$ artinya bila perempuan bekerja naik $1 \%$ ceteris paribus, maka pengangguran perempuan turun $0,5259 \%$ dan signifikan pada $\alpha=1 \%$. Hal ini sesuai dengan logika teori jika partisipasi wanita di pasar kerja meningkat, maka pengangguran perempuan menurun. Sementara itu, variabel inflasi $\left(\mathrm{X}_{3}\right)$ dan investasi $\left(\mathrm{X}_{4}\right)$ tidak signifikan mempengaruhi pengangguran perempuan.

Di dalam mengestimasi data panel dengan Random Effect, diasumsikan bahwa setiap propinsi di Indonesia mempunyai perbedaan intersep, dan juga diasumsikan bahwa intersep adalah random atau stokastik, sehingga ${ }_{0 i}$ dalam persamaan 2 tidak lagi tetap (non stokastik) tetapi bersifat random. Estimasi random effect antara propinsi dengan intersep $\mathrm{c}=-0,9437$ merupakan nilai rata-rata dari komponen kesalahan random (random error component). Nilai Random Effect menunjukkan seberapa besar perbedaan komponen kesalahan random suatu propinsi terhadap nilai intersep Indonesia (rata-rata). Misalkan pada propinsi Bali - 0,02712 yang menunjukkan seberapa besar perbedaan komponen kesalahan random Propinsi Bali dengan nilai intersep rata-rata Indonesia. Karena penjumlahan semua random effect akan menghasilkan angka nol.

\section{Partisipasi Pekerja Perempuan di Masing-masing Sektor}

Selama kurun waktu 2002 -2006, keterlibatan perempuan di pasar kerja untuk masing-masing sektor di setiap propinsi di Indonesia dapat dilihat pada grafik berikut. Ada beberapa propinsi yang digunakan sebagi sampel untuk menggambarkan perkembangan keterlibatan perempuan di pasar kerja pada setiap sektor, guna menunjang hasil yang menunjukkan bahwa peningkatan partisipasi perempuan di pasar kerja mampu menurunkan pengangguran perempuan. Berikut ini adalah sampel propinsi yang mempunyai karateristik tertentu.

Propinsi Nangroe Aceh Darusalam (NAD), dengan karateristik wilayahnya menunjukkan bahwa mayoritas perempuan bekerja di sektor jasa kemasyarakatan (9), sampai pada tahun 2003 mencapai angka $160.000(79 \%)$ sementara di sektor yang lain relatif stabil berkisar $15.000-40.000$ orang. 
Sementara di DKI Jakarta dan Jawa Timur, ada sedikit perbedaan, dimana di Jawa Timur perempuan bekerja di sektor jasa kemasyarakatan (9), pertaian dalam arti luas (1) 
Journal of Indonesian Applied Economics

Vol. 3 No. 2 Oktober 2009, 111-120
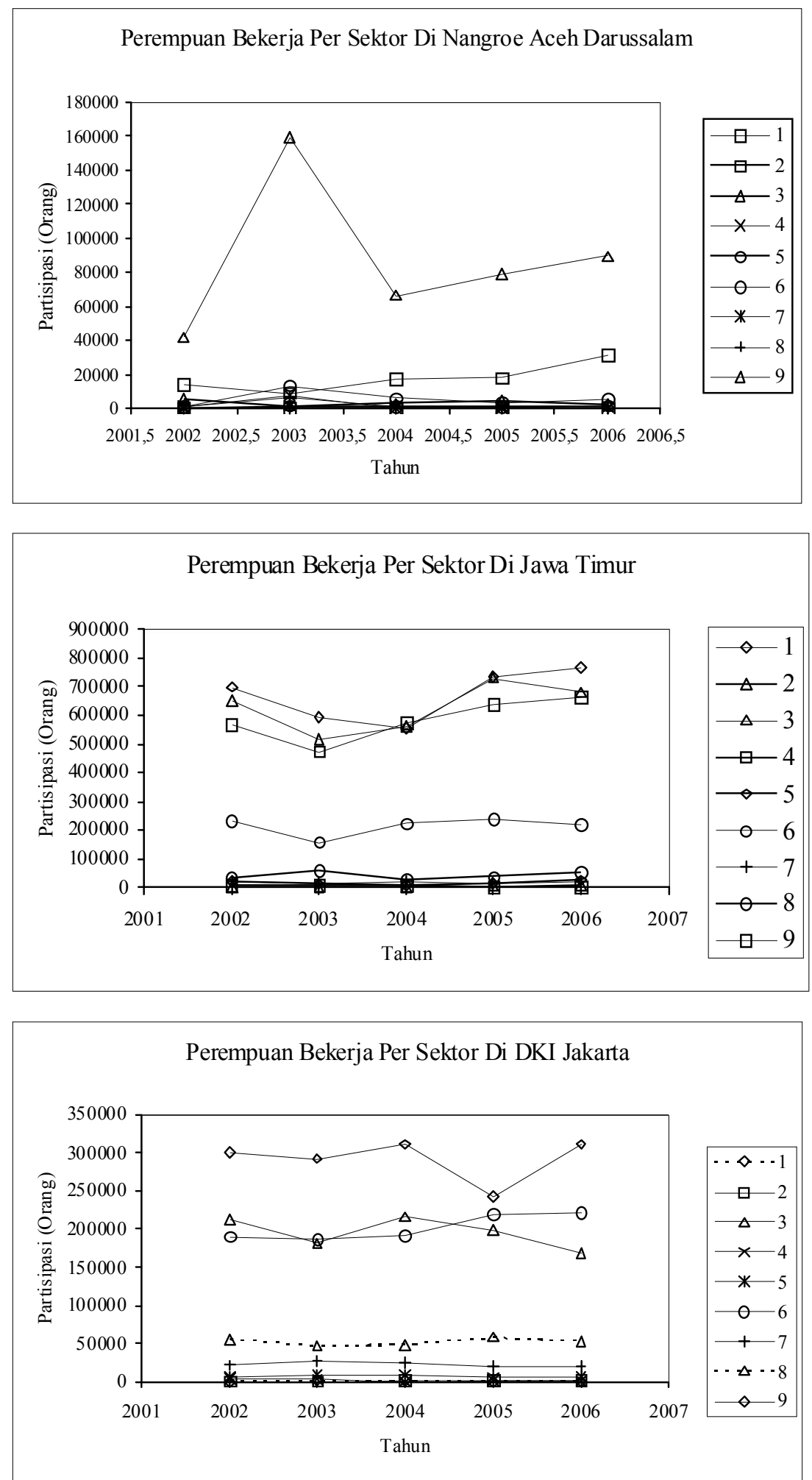

Gambar 1. Perempuan Bekerja per Sektor di NAD, DKI Jakarta dan Jawa Timur 


\section{Analisis Faktor-Faktor yang Mempengaruhi Perempuan \\ Ayu dan Kaluge}

dan industri pengolahan (3) relative sama berkisar antara 500.000 -700.000 (masing sekitar 26\%$30 \%$ ), sedangkan DKI Jakarta keterlibatan perempuan paling tinggi di sektor jasa kemasyarakatan, kemudian industri pengolahan dan perdagangan (6). Ini juga menunjukkan karateristik wilayah seperti Jakarta yang sangat sedikit lahan pertanian dibandingkan Jawa Timur.

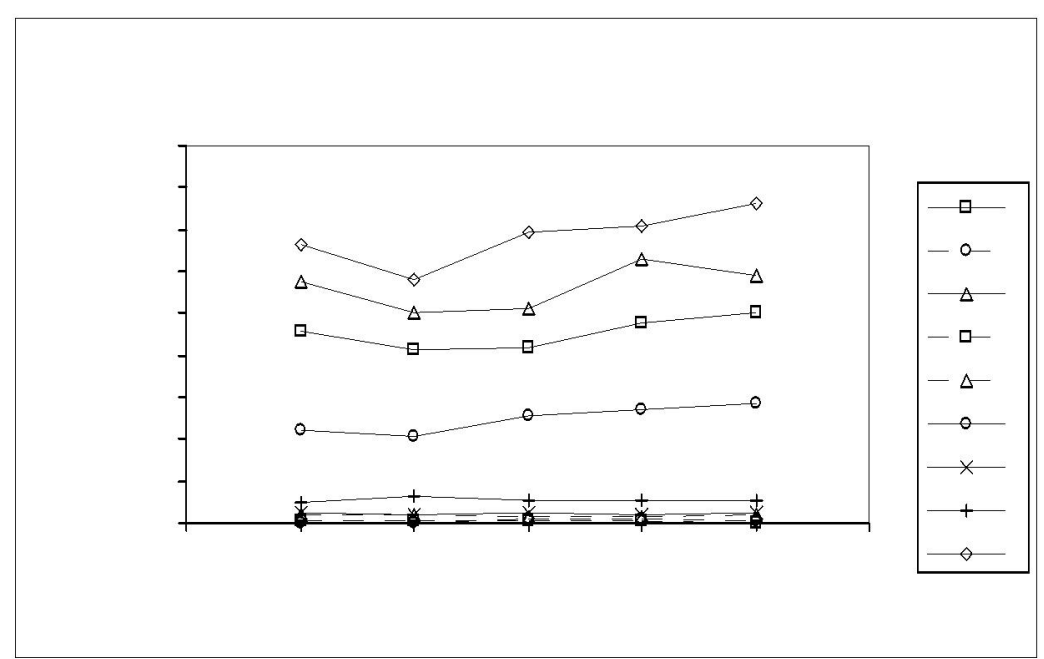

\section{Gambar 2. Perempuan Bekerja per Sektor di Indonesia}

Secara keseluruhan atau secara rata-rata di Indonesia bahwa keterlibatan perempuan di pasar kerja adalah di sektor jasa kemasyarakatan, industri, pertanian dan perdagangan relatif lebih banyak dibandingkan di sektor yang lain. Sudah tentu di masing-masing wilayah, sesuai dengan karateritik wilayah, budaya bekerja, adat istiadat serta struktur perekonomian setempat.

\section{E. KESIMPULAN DAN REKOMENDASI}

Selama periode pengamatan, hanya variabel perempuan bekerja yang signifikan mempengaruhi pengangguran perempuan dan sesuai dengan logika teori, yaitu peningkatan partisipasi perempuan di pasarkerja dapat menurunkan pengangguran perempuan. Sedangkan variabel laki-laki bekerja signifikan berpengaruh terhadap pengangguran perempuan, namun bertanda positif yang menunjukkan bahwa kesempatan kerja memang lebih banyak bagi laki-laki, sehingga walaupun laki-laki bekerja meningkat pengangguran perempuan bisa juga meningkat. Apalagi peningkatan kesempatan kerja di pasar kerja bagi perempuan tidak proporsional dengan peningkatan pencari kerja itu sendiri. Sementara inflasi dan investasi tidak signifikan berpengaruh terhadap pengangguran perempuan. Hasil random effect terpilih mampu menjelaskan seberapa besar perbedaan komponen kesalahan random setiap Propinsi dengan nilai intersep rata-rata Indonesia. Keterlibatan perempuan di pasar kerja, secara rata-rata relatif lebih banyak di sektor jasa kemasyarakatan, industri, pertanian dan perdagangan.

\section{REKOMENDASI}

Dalam pengambilan kebijakan yang berhubungan dengan pengangguran, kesempatan kerja, inflasi maupun investasi, disamping memperhatikan karateristik daerah yang dapat berpengaruh terhadap keterlibatan perempuan di pasar kerja, perlu juga memperhatikan peningkatan pencari kerja baik secara absolut maupun relatif, sehingga perencanaan investasi dengan tujuan menciptakan lapangan kerja bisa diharapkan. 
Journal of Indonesian Applied Economics

Vol. 3 No. 2 Oktober 2009, 111-120

\section{DAFTAR PUSTAKA}

Adil H. Mouhammed, 2006, Instability of capitalism inflation, unemployment, and business..., Zb.rad.Ekon.fak.Rij. vol 24: 165-184

Arrieta, G. M. G., 1988, Interest Rate, Saving and Growth in LDCs: An Assessment of Recent Empirical Research, World Development, Vol. 16: 589-605.

Barro, R. J., 1993, Macroeconomics, $4^{\text {th }}$ edition, John Wiley and Sons, Inc Toronto

Fakih Mansour, 1996, Gender Sebagai Alat Analisis Sosial, artikel.

Nothaft, Frank, 2006, The Unemployment-Inflation Trade-off Economic and Housing Outlook, The Economic Journal

Greene, 2000, Basic Econometrics, $4^{\text {th }}$ edition, McGraw-Hill, inc, New York.

Gujarati, Damodar, 2000, Basic Econometrics, $4^{\text {th }}$ edition, McGraw-Hill, inc, New York.

Hsiao, Cheng, 1995, Analysis of Panel Data, Cambridge University Press.

Mason, Andrew, 1988, Saving economic Growth and Demographic Change, Population and Development Review, Vol. 12 No. 1 Maret 113-144.

McKinnon, Ronald I, 1973, Money and Capital in Economic Development, Washington: Brookings Institution.

Smith, Ron and Zoega, Gylfi, 2006, The Economic Journal, vol 116, p 1-8

Pasinetti, Luigi, 1962, Rate of Profit and Income Distribution in relation to the Rate of Economic Growth, Review of Economic Studies. Vol 29: 267-279.

Vieneris, Y.P, 1997, Macroeconomic Model and Policy, John Wiley \& Son, New York. 